\title{
Asthma in the workplace: A Canadian contribution and perspective
}

\author{
Jean-Luc Malo MD¹, Moira Chan-Yeung $\mathrm{MB}^{2}$
}

\begin{abstract}
A lthough there were previous relevant contributions to the field of asthma in the workplace (AWP), Professor Jack Pepys is rightly considered to be the father of the discipline (1). In the 1970s, he popularized the use of simulated exposure testing to confirm the diagnosis of occupational asthma (OA) and reported many different causes as well as agents responsible for OA. He trained many students from different parts of the world; some of whom migrated to Canada. Table 1 shows the developments in research in different aspects of OA over the past three decades, mostly by Canadian investigators. It should therefore come as no surprise that AWP is an important research theme in this country.
\end{abstract}

\section{DEFINITION}

Whereas interest was until recently almost entirely focused on $\mathrm{OA}$, ie, asthma caused by the workplace, clinicians and researchers have broadened their work on AWP, an entity that includes not only OA but also work-aggravated asthma and variants (Figure 1). Moreover, because of the results presented in a book co-written by Canadian and American authors (2), OA, as such, now encompasses two entities: the immunological type with a latency period that occurs as a result of 'sensitization' to an agent present in the workplace, and the irritant type without a latency period that occurs after accidental inhalation of a product (irritant-induced asthma [IrIA] or reactive airways disease syndrome) (2). Among variants, occupational eosinophilic bronchitis was initially described by Canadian physicians (3) and is now more frequently reported (4). This condition is characterized by coughing and the presence of increased levels of eosinophils in induced sputum. It is currently recognized that work-aggravated asthma may have as many socioeconomic consequences as $\mathrm{OA}(5)$, thus warranting better identification. This condition represents symptomatic worsening of asthma that occurs at work, but little is known about its etiology and mechanisms (6).

\section{AGENTS CAUSING OA}

At present, over 300 compounds have been described as being responsible for OA. A list of these compounds can be found on various Web sites as well as in the book Asthma in the Workplace (7). They can be divided into two groups: high molecular weight (HMW) compounds and low molecular weight (LMW) compounds.

Studies of western red cedar asthma reported by Chan-Yeung et al (8) in Vancouver, British Columbia, in the early 1970s have provided a unique opportunity to examine several aspects of OA. Western red cedar asthma had already been reported in Australia; however, Chan-Yeung and her group were successful in isolating plicatic acid, a unique chemical in western red and eastern white cedar shown to be responsible for asthma by using inhalation challenge testing (9). Plicatic acid is a LMW compound and has a molecular weight of $440 \mathrm{Da}$. Because this is a relatively common condition in the Pacific Northwest, her team was able, over the next two decades, to study the clinical feature, epidemiology, natural history and pathogenesis of this disease as a model of OA due to LMW compounds. On the Atlantic coast, studies (10) of snow crab-induced OA in the Îles de la Madeleine, Quebec, have provided an opportunity to examine the natural history of the condition by focusing on the time-course of recovery after cessation of exposure. This information was useful in setting criteria for the assessment of impairment or disability.

The main agents causing irritant-induced $\mathrm{OA}$ are chlorine and ammonia, although, theoretically, all types of agents can cause this condition if the concentrations of exposure are excessive.

\section{FREQUENCY, HOST AND ENVIRONMENTAL FACTORS}

There have been a number of prevalence studies of asthma in high-risk industries in Canada, such as western red cedar sawmills and snow crab processing, among others (Table 1). The prevalence of $\mathrm{OA}$ in different industries varies considerably, partly due to the level of exposure and partly due to the type of agents involved, because some agents are likely to be more asthmagenic (such as diisocyanates) than others.

Data collected through notification programs and voluntary reporting in British Columbia (11) and Quebec (12), originally proposed in the United Kingdom as a valuable tool (13), found that the frequencies of $\mathrm{OA}$ were 22 cases and (approximately) 60 cases per million workers per year, respectively. These figures may demonstrate over-reporting because there are approximately 15 accepted cases of OA per million workers per year in Quebec (14) according to medicolegal statistics, another interesting source of information.

The population attributable risk of asthma was estimated to be approximately $15 \%$ in many countries that took part in the vast European Community Respiratory Health Survey (ECRHS) (15). As part of the prevalence study of asthma and asthma symptoms among 20- to 44-year-old subjects in six cities across Canada, the population attributable risk of occupational exposure to what was labelled probable OA was 16.3\% (95\% CI

${ }^{1}$ Department of Chest Medicine, Hôpital du Sacré-Coeur de Montréal, Montreal, Quebec; ${ }^{2}$ Occupational and Environmental Lung Disease Unit, Respiratory Division, Department of Medicine, University of British Columbia, Vancouver, British Columbia

Correspondence: Dr Jean-Luc Malo, Department of Chest Medicine, Hôpital du Sacré-Coeur de Montréal, 5400 West Gouin Boulevard,

Montreal, Quebec H4J 1C5. Telephone 514-338-2796, fax 514-338-3123, e-mail malojl@meddir.umontreal.ca 
TABLE 1

A summary of contributions of investigators before 1970 and of Canadian investigators in various aspects of occupational asthma (OA) in the past three decades

\begin{tabular}{|c|c|c|c|c|c|c|c|}
\hline Date & Agents & Diagnostic methods & Epidemiology & Natural history & Pathogenesis & $\begin{array}{c}\text { Compensation } \\
\text { issue }\end{array}$ & Prevention \\
\hline $\begin{array}{r}\text { Before } \\
1900\end{array}$ & $\begin{array}{l}\text { Grain dust (Thackrah); } \\
\text { coffee bean; asthma } \\
\text { in maltsters, hatters } \\
\text { and hairdressers; } \\
\text { and ipecacuanha }\end{array}$ & $\begin{array}{l}\text { History (Ramazzini), } \\
\text { spirometry (Thackrah) }\end{array}$ & & & & & \\
\hline $\begin{array}{r}1900- \\
1960\end{array}$ & $\begin{array}{l}\text { HMW: Castor bean, } \\
\text { gum arabic, mayfly, } \\
\text { locust, flour } \\
\text { LMW: Isocyanates } \\
\text { Irritants: Chlorine, } \\
\text { gases used in } \\
\text { World War I }\end{array}$ & $\begin{array}{l}\text { Inhalation testing with } \\
\text { HMW compounds } \\
\text { (Colldahl) and } \\
\text { LMW compounds } \\
\text { (Gelfand) by } \\
\text { aerosolization }\end{array}$ & & & $\begin{array}{l}\text { Positive skin tests } \\
\text { to specific HMW } \\
\text { allergens }\end{array}$ & & \\
\hline $\begin{array}{r}1971- \\
1980\end{array}$ & $\begin{array}{l}\text { HMW: Bacillus subtilis, } \\
\text { papain } \\
\text { LMW: Ethylenediamine, } \\
\text { monoethanolamine, } \\
\text { ammonia thioglycate, } \\
\text { western red cedar, } \\
\text { piperazine, platinum, } \\
\text { phthalate anhydride, } \\
\text { spiramycin, } \\
\text { persulphate, henna, } \\
\text { rosin, potroom } \\
\text { asthma }\end{array}$ & $\begin{array}{l}\text { Simulated occupational } \\
\text { exposure testing (Pepys) } \\
\text { Different types of asthmatic } \\
\text { reactions from exposure } \\
\text { testing: early, late and } \\
\text { biphasic } \\
\text { Standardization of } \\
\text { methacholine/histamine } \\
\text { challenge testing } \\
\text { Serial monitoring of PEF } \\
\text { and of NSBH } \\
\text { Standardization of serial } \\
\text { monitoring of PEF }\end{array}$ & $\begin{array}{l}\text { Prevalence studies } \\
\text { of workers in } \\
\text { British Columbia } \\
\text { in red cedar } \\
\text { sawmills, grain } \\
\text { elevators, } \\
\text { aluminum smelters, } \\
\text { and pulp mills }\end{array}$ & $\begin{array}{l}\text { Follow-up studies } \\
\text { showing a high } \\
\text { percentage of } \\
\text { patients with red } \\
\text { cedar asthma } \\
\text { failed to recover } \\
\text { after removal } \\
\text { from exposure; } \\
\text { recovery } \\
\text { depended on } \\
\text { duration of } \\
\text { exposure }\end{array}$ & $\begin{array}{l}\text { HMW compounds IgE- } \\
\text { mediated type I } \\
\text { allergic reaction } \\
\text { responsible for early } \\
\text { asthmatic reaction; } \\
\text { Demonstration that } \\
\text { LMW compounds act } \\
\text { as haptens to } \\
\text { combine with a body } \\
\text { protein; early } \\
\text { asthmatic response } \\
\text { is IgE-mediated. Eg, } \\
\text { platinum. Others are } \\
\text { not (eg, TDI) }\end{array}$ & $\begin{array}{l}\text { OA recognized as a } \\
\text { compensable } \\
\text { disease in both } \\
\text { Quebec and } \\
\text { British Columbia }\end{array}$ & \\
\hline $\begin{array}{r}1981- \\
1990\end{array}$ & $\begin{array}{l}\text { HMW: Pepsin, crab } \\
\text { processing, psyllium, } \\
\text { guar gum, gluten, } \\
\text { latex } \\
\text { LMW: California red } \\
\text { wood, ash wood, } \\
\text { eastern white cedar, } \\
\text { penicillamine, } \\
\text { hydralazine, nickel, } \\
\text { azobisformamide }\end{array}$ & & $\begin{array}{l}\text { Prevalence studies: } \\
\text { crab processing, } \\
\text { eastern white cedar, } \\
\text { psyllium, spiramycin, } \\
\text { guar gum, isocyanate } \\
\text { Dose-relationship } \\
\text { established between } \\
\text { exposure and } \\
\text { prevalence of red } \\
\text { cedar asthma } \\
\text { Prevalence of irritant- } \\
\text { induced asthma in } \\
\text { OA clinic }\end{array}$ & $\begin{array}{l}\text { Follow-up studies } \\
\text { of patients with } \\
\text { snow crab } \\
\text { asthma and a } \\
\text { number of } \\
\text { other agents } \\
\text { confirming the } \\
\text { above finding }\end{array}$ & $\begin{array}{l}\text { Persistence of asthma } \\
\text { symptoms after } \\
\text { removal was related } \\
\text { to persistent cellular } \\
\text { changes in airways } \\
\text { and evidence of } \\
\text { airway remodelling } \\
\text { Animal model of red } \\
\text { cedar sensitization }\end{array}$ & $\begin{array}{l}\text { Persistent asthma } \\
\text { recognized by } \\
\text { compensation } \\
\text { boards as an } \\
\text { outcome }\end{array}$ & \\
\hline $\begin{array}{r}1991- \\
2000\end{array}$ & $\begin{array}{l}\text { HMW: Lobster, shrimp, } \\
\text { clam, oak dust, } \\
\text { aromatic herbs, } \\
\text { cacao, pectin, } \\
\text { LMW: Diacrylate, } \\
\text { resin, formaldehyde }\end{array}$ & $\begin{array}{l}\text { Closed circuit method of } \\
\text { inhalation challenge } \\
\text { testing for particles and } \\
\text { aerosols with monitoring } \\
\text { of levels } \\
\text { Standardization of methods } \\
\text { of induction of sputum and } \\
\text { eosinophil measurements }\end{array}$ & $\begin{array}{l}\text { Surveillance program } \\
\text { of OA in British } \\
\text { Columbia and } \\
\text { Quebec } \\
\text { Prospective studies } \\
\text { of students trained } \\
\text { for laboratory animal } \\
\text { handling, dental } \\
\text { technicians and } \\
\text { bakers }\end{array}$ & $\begin{array}{l}\text { Rhinoconjunctivitis } \\
\text { precedes the } \\
\text { development of } \\
\text { asthma and may } \\
\text { serve as an early } \\
\text { marker }\end{array}$ & $\begin{array}{l}\text { T-lymphocyte probably } \\
\text { played a role in the } \\
\text { pathogenesis of } \\
\text { LMW compounds } \\
\text { Pathology of RADS } \\
\text { diffuse desquamation } \\
\text { of bronchial epithelium, } \\
\text { cellular infiltration } \\
\text { Animal model of RADS }\end{array}$ & $\begin{array}{l}\text { Recognition that } \\
\text { respiratory } \\
\text { impairment rating } \\
\text { for asthma should } \\
\text { be different from } \\
\text { irreversible lung } \\
\text { disease } \\
\text { ATS statement on } \\
\text { respiratory impairment } \\
\text { or disability evaluation } \\
\text { in asthmatics to } \\
\text { include lung function, } \\
\text { medication requirement } \\
\text { and NSBH }\end{array}$ & $\begin{array}{l}\text { Medical } \\
\text { surveillance } \\
\text { program of } \\
\text { workers } \\
\text { exposed to } \\
\text { isocyanates } \\
\text { resulted in } \\
\text { reduced } \\
\text { isocyanate- } \\
\text { induced } \\
\text { asthma }\end{array}$ \\
\hline $\begin{array}{l}\text { After } \\
2001\end{array}$ & $\begin{array}{l}\text { HMW: Liquorice roots, } \\
\text { work-aggravated } \\
\text { asthma }\end{array}$ & $\begin{array}{l}\text { Measurement of sputum } \\
\text { eosinophils or exhaled } \\
\text { nitric oxide }\end{array}$ & $\begin{array}{l}\text { Prevalence of OA in } \\
\text { six cities in Canada }\end{array}$ & & $\begin{array}{l}\text { Studies of genetics of } \\
\text { OA }\end{array}$ & $\begin{array}{l}\text { AMA recognized ATS } \\
\text { method of rating of } \\
\text { respiratory impairment } \\
\text { or disability evaluation } \\
\text { in patients with } \\
\text { asthma }\end{array}$ & $\begin{array}{l}\text { Natural rubber } \\
\text { latex control } \\
\text { program in } \\
\text { Ontario resulted } \\
\text { in reduction in } \\
\text { sensitization, OA } \\
\text { and severity of } \\
\text { symptoms due } \\
\text { to latex in dental } \\
\text { school students } \\
\text { and staff }\end{array}$ \\
\hline
\end{tabular}

AMA American Medical Association; ATS American Thoracic Society; HMW High molecular weight; LMW Low molecular weight; NSBH Nonspecific bronchial hyperreactivity; PEF Peak expiratory flow; RADS Reactive airways dysfunction syndrome; TDI Toluene diisocyanate 
12.6 to 20.0) (16). In most of the population-based studies, the diagnosis of $\mathrm{OA}$ is not confirmed by objective procedures; therefore, it is likely that the majority of cases represent workaggravated asthma.

In a specialized asthma clinic in Toronto, Ontario, cases of probable OA represent approximately $15 \%$ of referrals (17). Irritant-induced OA represents $15 \%$ of all OA cases in Ontario (18).

It is now well established that both exposure and host factors are important in the development of OA. Although it has been known for a long time that the prevalence of pneumoconiosis is related to the level of exposure, this was not so with asthma or OA, which was believed to be a disease due mostly to individual hypersensitivity and not to levels of exposure. The development of sensitive methods of environmental monitoring of chemicals and proteins, in addition to the inclusion of environmental monitoring in epidemiological studies, changed this dogma. A dose-dependent relationship was found between the degree of exposure and the prevalence of asthma in red cedar sawmills (19) as well as in a number of other highrisk industries of exposure, including isocyanates, flour, amylase, rosin, laboratory animals and others, and permissible concentrations have been proposed, especially in relation to the exposure to flour (20). In the case of IrIA, there is also a dose-dependent likelihood to be left with symptoms if exposure is higher.

Atopy has been consistently documented as a risk factor for OA (although to a lesser extent than exposure), due to HMW compounds and for LMW compounds mediated by specific immunoglobulin E ( $\mathrm{IgE}$ ) antibodies, but not other LMW compounds such as diisocyanates and plicatic acid that are not mediated by specific IgE antibodies. Prospective studies in apprentices exposed to HMW agents (laboratory animals, flour and latex) carried out by Gautrin and Malo $(21,22)$ in Montreal have shown that atopy carries a risk of close to two. In apprentices exposed to laboratory animals, specific sensitization to pets on entry into the program showed a risk of close to four in relation to the risk of probable OA (22). Determinants for the development of specific sensitization, symptoms and disease may differ in atopic and nonatopic subjects (23). Baseline rhinitis symptoms and skin sensitization related to pets were associated with the development of work-related rhinoconjunctivitis symptoms in atopic subjects, whereas perennial rhinitis symptoms and having a provocative concentration of methacholine causing a 20\% fall in forced expiratory volume in $1 \mathrm{~s}$ value of $32 \mathrm{mg} / \mathrm{mL}$ or less were associated in nonatopic subjects.

Human leukocyte antigen polymorphisms have been associated with certain types of OA caused by chemicals such as diisocyanates and plicatic acid, but most studies were based on small sample sizes. These findings could not be replicated partly because of ethnic differences in genes and partly because geneenvironment interactions have not yet been established.

Socioeconomic factors can also make workers more likely to be affected with AWP (24). In Ontario, Tarlo et al (25) showed that low socioeconomic status and education increase the delay for referral, making workers more likely to develop permanent disability if they suffer from OA.

\section{PATHOGENIC MECHANISMS}

Pepys and Hutchcroft (26) described the different types of asthmatic reactions induced by agents responsible for OA: the

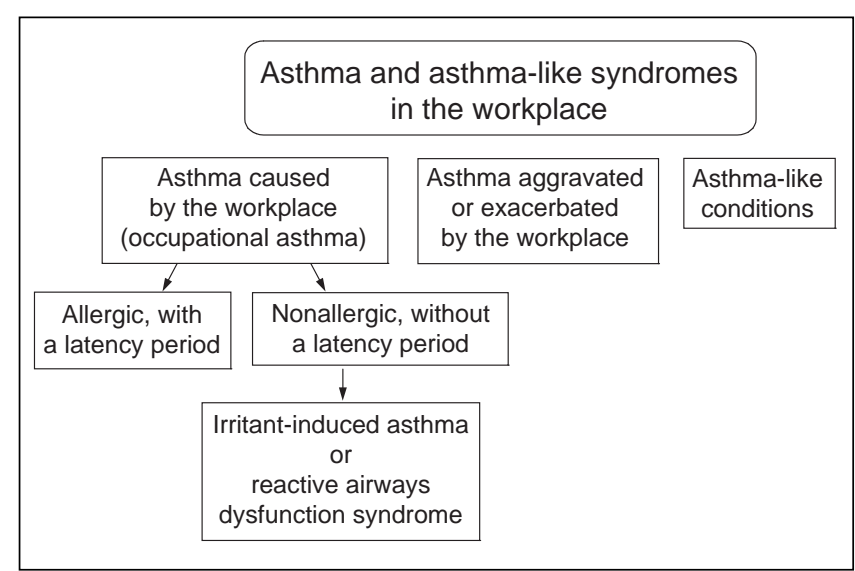

Figure 1) Varieties of asthma and asthma-like syndromes in the workplace

early type that occurs within minutes of inhalation challenge and subsides within $1 \mathrm{~h}$; late asthmatic reactions that occur several hours ( $4 \mathrm{~h}$ to $8 \mathrm{~h}$ ) after inhalation challenges lasting $12 \mathrm{~h}$ to $24 \mathrm{~h}$; and biphasic reactions, an early component with recovery followed by a late component several hours later. Later, it was noted that some of the late asthmatic reactions can occur after approximately $2 \mathrm{~h}$, and the reaction may not be biphasic but more like one continuous reaction, starting minutes after challenge and persisting for $24 \mathrm{~h}$ (27). Sometimes recurrent nocturnal reactions can occur after a single challenge test.

While inhalation challenge with HMW compounds usually induces an immediate asthmatic reaction or biphasic reaction, inhalation challenge with LMW compounds is usually associated with an isolated late asthmatic reaction.

The mechanisms for early and late asthmatic reactions have been widely studied. It is generally agreed that the induction of specific IgE antibodies is the pathway by which HMW compounds induce asthma, and that re-exposure at work or inhalation challenge testing leads to an $\mathrm{IgE}$-antigen reaction, releasing mediators such as histamine, cytokines and chemokines. Sensitization to HMW compounds can be demonstrated by either the allergy skin test or the presence of specific IgE antibodies. With some LMW compounds, such as platinum salts, specific IgE antibodies have been demonstrated; in this situation, the LMW compounds act as haptens and combine with a body protein to form a complete antigen. However, for some other LMW compounds such as diisocyanates (28) or plicatic acid (29), specific IgE antibodies are generally found in only a small proportion of workers with OA. For diisocyanates, specific $\operatorname{IgG}$ antibodies are more often found, and monocyte chemoattractant protein-1 seems more specific and sensitive for OA (28).

There is evidence that $\mathrm{T}$ cells are actively involved in OA. This hypothesis has been substantiated by the finding of proliferation of peripheral blood lymphocytes when subjects with asthma were stimulated with the appropriate antigen such as western red cedar (30) and other agents.

The pathology of IrIA differs from OA with a latency period. It is characterized by massive desquamation followed by basal cell regeneration, muscle hyperplasia and major collagen deposition both in humans (in a few patients who underwent bronchial biopsies [31]) and in rat (32) and mouse (33) models. The intense subepithelial fibrosis found in these patients is 


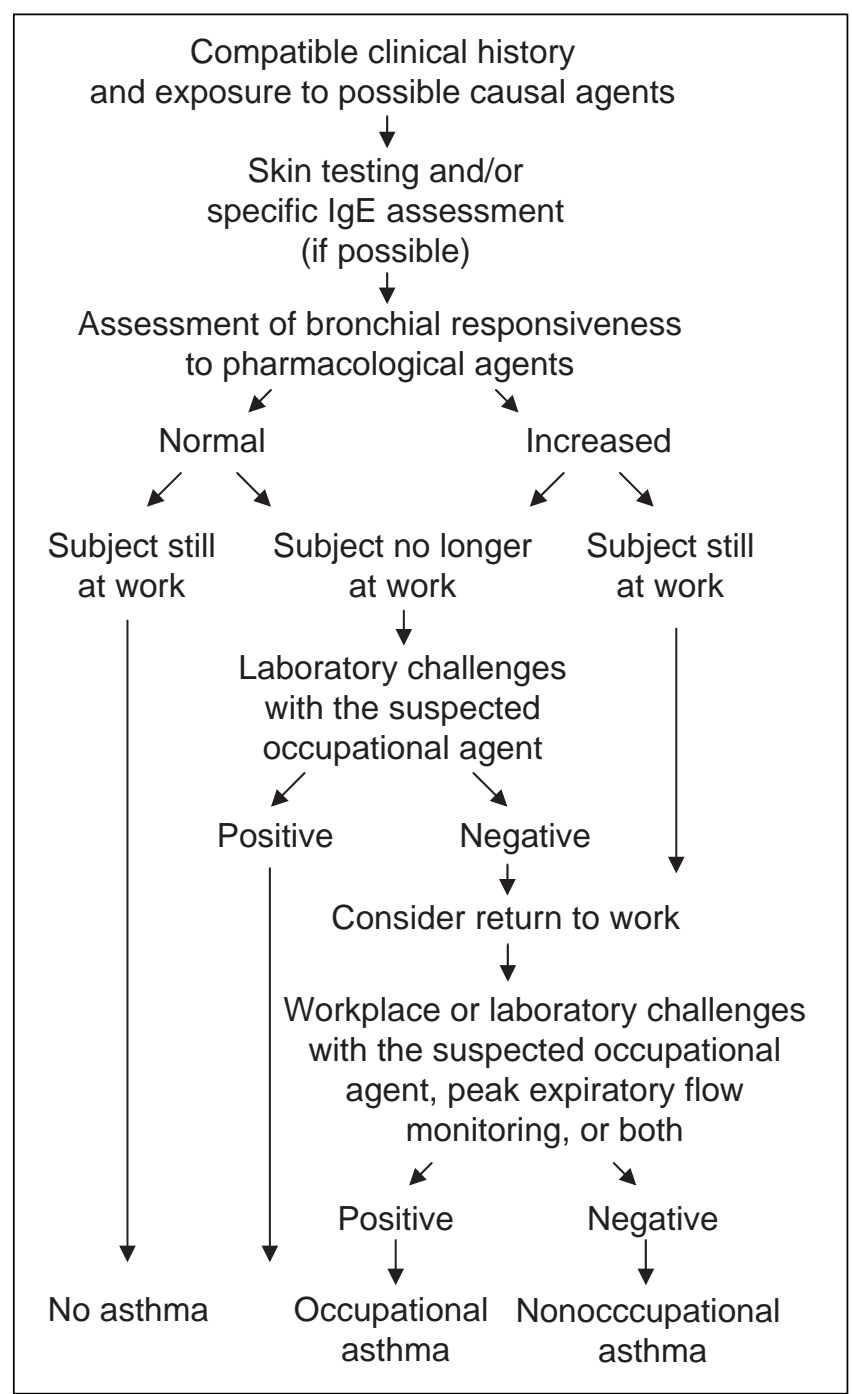

Figure 2) Stepwise investigation of asthma in the workplace. Adapted from reference 68. IgE Immunoglobulin $E$

probably responsible for the reduced reversibility of airflow obstruction observed in IrIA compared with other types of OA (34).

Some agents may induce asthma through both immunological and nonimmunological mechanisms. The best example is diisocyanates. Toluene diisocyanate-induced asthma occurs frequently in individuals who have previously been heavily exposed to the chemical in a spill. It is possible that the epithelial damage arising from the spill leads to increased penetration by the diisocyanates into the subepithelial tissue, thus leading to sensitization.

\section{DIAGNOSIS}

The first consensus guideline on AWP was an initiative of the Canadian Thoracic Society (35). The main problems that face practice related to AWP are under-reporting, too long delays in suspecting the condition that results in more important longterm sequelae, and failure to use objective tools to properly identify the condition. Canadian researchers were the first to suspect that asthma can persist even after removal from exposure, and that the longer the exposure with symptoms, the more likely asthma is to persist (36). This concept was innovative because at the time, clinicians used to think that asthma may be cured if a worker were no longer exposed to the agent that caused his or her asthma. Asthma is also more severe when it is work-related (37).

Diagnosing OA should be applied in a stepwise manner as illustrated in Figure 2. Although several objective tools have been developed over the years to better diagnose OA, as for asthma that is not sufficiently assessed by spirometry and by bronchial responsiveness to pharmacological agents, the diagnosis too often relies on a clinical questionnaire that has a low predictive value (38). Even the often suggested questions ("Does your asthma worsen at work?" or "Does your asthma improve at weekends or during vacations?") do not satisfactorily discriminate among OA, non-OA and neither condition (38).

Canadian researchers have validated the use of a jobexposure matrix in which both job title and exposure, along with international classification, are used in ascertaining a worker's risk of suffering from OA (39).

The model originally proposed by Tiffeneau in France and updated by Cockcroft et al (40) at McMaster, which combines the information obtained from immunological results (skin tests for the relevant occupational agent if the agent is a HMW agent) and reactivity to methacholine, can be used to ascertain the diagnosis. Having significantly increased specific IgE antibodies to HMW agents and having bronchial hyper-responsiveness result in a high likelihood that one will present an asthmatic reaction when exposed to an occupational allergen. Unfortunately, LMW chemical agents cannot be used for skin prick tests and can rarely be combined with human serum albumin to allow for obtaining specific IgE assessments. Although serial assessments of peak expiratory flow can be used in the diagnostic process, the 'gold standard' is still exposure followed by supervision of objective parameters either at the workplace or at the hospital laboratory. These tests, which were initially proposed by Professor Jack Pepys (41) at Brompton Hospital, are carried out in different hospitals in Canada. Clinicians and researchers at Hôpital du Sacré-Coeur in Montreal, Quebec, in conjunction with researchers of the Institut Robert-Sauvé en santé et sécurité du travail, Quebec, have developed closed-circuit apparatuses that facilitate exposing workers to stable and safe (42) concentrations of many agents reported as causing OA (43).

Monitoring of asthmatic reactions has long been carried out by using spirometry and bronchial responsiveness. Recent developments have outlined the need to monitor airway inflammation in asthma either with exhaled nitric oxide or with induced sputum. These tests can be applied to AWP, and Canadian physicians have validated this approach $(44,45)$. They have further shown that information on induced sputum can improve the accuracy of the diagnosis of OA made by examination of serial peak expiratory flow (46).

Whereas the diagnosis of OA with a latency period can be made using several objective tests, the diagnosis of IrIA relies on a history of exposure(s) to irritant concentrations of a product present at work, with bronchial hyper-responsiveness lasting for at least three months (34).

For the time being, the diagnosis of work-aggravated asthma is made by exclusion, ie, the diagnosis is kept in the case of a worker with worsening of asthmatic symptoms at work in whom OA has been ruled out. Most of the time, worsening of symptoms cannot be confirmed with objective tests. Lemière 
et al (45) have shown that these workers show an increase in sputum neutrophils at work, whereas subjects with OA have increased levels of eosinophils.

\section{OUTCOME}

The outcome of OA has been described by several Canadian investigators. In 1977, Chan-Yeung (36) was the first to report persistence of asthma in the majority of patients with western red cedar asthma after removal from exposure, and in 1982, Chan-Yeung et al (47) confirmed the findings in a much larger study. This finding has been replicated in patients with OA due to snow crab and other agents by Hudson et al (48). Approximately $75 \%$ of workers with OA are left with permanent hyper-responsiveness even after removal from exposure to the causal agent, although the magnitude of their asthma symptoms is generally mild. Airway inflammation may persist for a long time after stopping exposure, even in apparently cured patients $(49,50)$. Maximum improvement occurs in the first two years after cessation of exposure but there is still improvement afterwards, although at a slower pace (51). In irritant-induced OA, Malo et al (52) found that the pattern of improvement is similar to allergic OA in the first two years after the inhalation accident.

In patients with allergic OA who remain exposed to the causal agent, asthma is likely to worsen and an accelerated decline of pulmonary function (forced expiratory volume in 1 s) may occur (53).

\section{MANAGEMENT, OUTCOME AND MEDICOLEGAL ISSUES}

Once the diagnosis of OA is made, it is necessary for the worker to stop exposure, find alternative employment and commence treatment with inhaled steroids that can hasten improvement (54). Continuous exposure is likely to be associated with progressive deterioration of asthma (53). In some instances (eg, isocyanate-induced asthma), the use of full face masks can be considered. Reduced exposure is not a satisfactory option to suggest, although socioeconomic issues may force a worker to remain at his/her workplace with reduced exposure.

While pneumoconiosis had been recognized as a compensable disease for a long time in Canada, OA was not recognized until 1970. In Quebec, once the diagnosis of OA is confirmed through reference by Workers' Compensation Board committees (there are four) to pneumologists at one of the two referral centres (Sacré-Coeur Hospital in Montreal and Laval Hospital in Quebec City, Quebec), rehabilitation programs are offered (55). These include retraining programs and, in some instances, offers to further education because, as is often the case with OA, affected workers are young, unlike pneumoconiosis (asbestosis and silicosis). This scheme provides workers with a full salary, generally for up to two years, which is the time required for retraining for a new occupation for workers who can no longer stay with their current employer. The cost of the program was estimated to be $\$ 50,000$ for each case of OA for the period 1986 to 1988 ; it is approximately $\$ 75,000$ at present. However, in other provinces of Canada, such a welldefined program is still not in existence.

For a while, respiratory impairment or disability assessment for patients with OA was carried out in the same way as for pneumoconiosis, which is irreversible and was based entirely on the lung function results. This was most unfair for workers with asthma, whose lung function tends to vary and improve considerably with treatment. Even when their lung function is normal, these patients cannot return to their usual job with the same exposure. Moreover, bronchial hyper-responsiveness makes workers with OA less likely to be employable. Scales were developed initially in Quebec (56) for assessing impairment or disability for asthma to include not only airway calibre, but also the need for medication to control asthma and the degree of bronchial hyper-responsiveness. A variation of this scale was accepted by the American Thoracic Society in 1993 (57) and later adapted by the American Medical Association for evaluation of patients with asthma in general (58). The impairment scores arising from using these three parameters correlated well with the degree of airway inflammation, as reflected by the number of eosinophils in induced sputum (59). Because improvement was initially found to plateau after two years, it has been suggested that workers should be assessed two years after cessation of exposure (10). Later, further research showed that improvement may occur after two years (8).

The health-related quality of life is often impaired in workers with $\mathrm{OA}$, although the impact is generally low as long as satisfactory rehabilitation programs are offered (60) or if there are possibilities of working in the same workplace without being exposed, as shown in Ontario in hospital workers with OA due to latex (61)

\section{PREVENTION}

As outlined by Tarlo and Liss (62), potential primary preventive measures include the following: eliminate a responsible agent by substitution with safer substances or chemicals; reduce exposure by using engineering controls such as improved ventilation process or equipment modification, process enclosure, dust reduction techniques, housekeeping and work practices; administrative controls to reduce the number of workers exposed or duration of exposure, eg, job rotation, rest periods, shift or location changes in which fewer people are working with sensitizers or irritant exposures; use of personal protective equipment (by the worker), which includes respirators, gloves, goggles and coveralls; and limit exposure to potential respiratory irritants among those with pre-existing asthma to reduce work-related aggravation of asthma.

Exclusion of susceptible workers has been successful in platinum refinery workers, but this means that $50 \%$ of the available workforce is excluded, which is considered ineffective and unethical.

Very few surveillance programs have been carried out to assess the efficacy and effectiveness of primary prevention, and most of the programs have methodological limitations (63).

Available data suggest that environmental control strategies (often associated with secondary prevention programs) have been effective in reducing the development of OA and occupational rhinitis in workers exposed to detergent enzymes and latex gloves. It is not certain whether this applies to diisocyanates. Tarlo and Liss (64) showed a reduction in the number of cases of OA due to diisocyanates in Ontario, but this fall in the number of cases from 1995 onwards was also documented in Quebec, where such a surveillance program was not applied (65).

Secondary preventive measures are aimed at detecting indicators of early sensitization or early changes of allergic OA before there is persistent and/or severe disease (62). In at-risk subjects, medical surveillance programs for allergic 


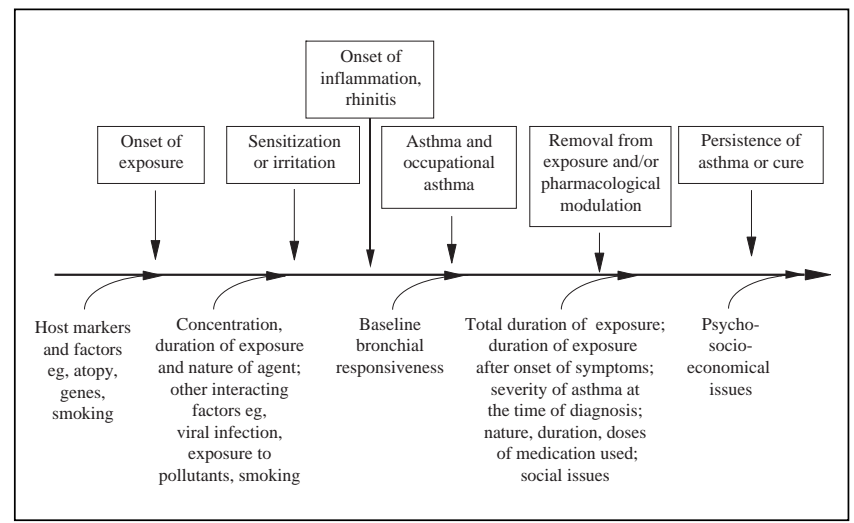

Figure 3) Natural history of asthma and occupational asthma

OA typically include a symptom questionnaire and, when possible, immunological tests and spirometry (62). Because sensitization and onset of symptoms show higher incidence figures in the first years after starting exposure (66), surveillance programs should be more intense in this interval.

\section{PERSPECTIVE}

Canadian physicians M Chan-Yeung, JL Malo and S Tarlo were the initiators of an international event, the Jack Pepys Workshop on Asthma in the Workplace, held every three years. This event is a forum of discussion, with leading presenters and discussants, at which over 100 key questions were raised (67). The third event, held in Montreal in May 2007, allowed participants to realize that some questions had already been answered, at least partially, since the Toronto meeting. The main points raised at the recent meeting dealt with the need for defining work-aggravated asthma, the importance of objective confirmation of diagnosis of OA, psychological considerations and impact on one's life, and the use of the model of OA to understand the natural history of asthma (Figure 3). It is likely that work, especially by Canadian physicians, will focus on these issues in the coming years.

ACKNOWLEDGEMENTS: The authors would like to thank Mrs Kathe Lieber for revising this manuscript.

\section{REFERENCES}

1. Pepys J, Bernstein IL. Historical aspects of occupational asthma. In: Bernstein IL, Chan-Yeung M, Malo JL, Bernstein DI, eds. Asthma in the Workplace, 3rd edn. New York: Taylor \& Francis, 2006:9-35.

2. Bernstein IL, Chan-Yeung M, Malo JL, Bernstein DI. Definition and classification of asthma in the workplace. In: Bernstein IL, Chan-Yeung M, Malo JL, Bernstein DI, eds. Asthma in the Workplace, 3rd edn. New York: Taylor \& Francis, 2006:1-8.

3. Lemière $\mathrm{C}$, Efthimiadis $\mathrm{A}$, Hargreave FE. Occupational eosinophilic bronchitis without asthma: An unknown occupational airway disease. J Allergy Clin Immunol 1997;100:852-3.

4. Quirce S. Eosinophilic bronchitis in the workplace. Curr Opin Allergy Clin Immunol 2004;4:87-91.

5. Vandenplas $\mathrm{O}$, Toren K, Blanc PD. Health and socioeconomic impact of work-related asthma. Eur Respir J 2003;22:689-97.

6. Vandenplas O, Malo JL. Definitions and types of work-related asthma: A nosological approach. Eur Respir J 2003;21:706-12.

7. Malo JL, Chan-Yeung M. Appendix: Agents causing occupational asthma with key references. In: Bernstein IL, Chan-Yeung M, Malo JL, Bernstein DI, eds. Asthma in the Workplace, 3rd edn. New York: Taylor \& Francis, 2006:825-66.
8. Chan-Yeung M, Barton GM, McLean L, Grzybowski S. Bronchial reactions to western red cedar (Thuja plicata). Can Med Assoc J 1971;105:56-8

9. Chan-Yeung M, Barton GM, MacLean L, Grzybowski S. Occupational asthma and rhinitis due to Western red cedar (Thuja plicata). Am Rev Respir Dis 1973;108:1094-102.

10. Malo JL, Cartier A, Ghezzo H, Lafrance M, Mccants M, Lehrer SB. Patterns of improvement in spirometry, bronchial hyperresponsiveness, and specific IgE antibody levels after cessation of exposure in occupational asthma caused by snow-crab processing. Am Rev Respir Dis $1988 ; 138: 807-12$.

11. Contreras GR, Rousseau R, Chan-Yeung M. Occupational respiratory diseases in British Columbia, Canada in 1991. Occup Environ Med 1994;51:710-2.

12. Provencher S, Labrèche FP, De Guire L. Physician based surveillance system for occupational respiratory diseases: The experience of PROPULSE, Québec, Canada. Occup Environ Med 1997;54:272-6

13. Sallie BA, Ross DJ, Meredith SK, McDonald JC. SWORD ' 93. Surveillance of work-related and occupational respiratory disease in the UK. Occup Med (Lond) 1994;44:177-82.

14. Becklake MR, Chan-Yeung M, Malo JL. Epidemiological approaches in occupational asthma. In: Bernstein IL, Chan-Yeung M, Malo JL, Bernstein DI, eds. Asthma in the Workplace, 3rd edn. New York: Taylor \& Francis, 2006:37-85

15. Janson C, Anto J, Burney P, et al; on behalf of the European Community Respiratory Health Survey II. The European Community Respiratory Health Survey: What are the main results so far? Eur Repir J 2001;18:598-611.

16. Johnson AR, Dimich-Ward HD, Manfreda J, et al. Occupational asthma in adults in six Canadian communities. Am J Respir Crit Care Med 2000;162:2058-62.

17. Tarlo SM, Leung K, Broder I, Silverman F, Holness DL. Asthmatic subjects symptomatically worse at work: Prevalence and characterization among a general asthma clinic population. Chest 2000;118:1309-14.

18. Tarlo SM, Broder I. Irritant-induced occupational asthma. Chest 1989;96:297-300.

19. Vedal S, Chan-Yeung M, Enarson D, et al. Symptoms and pulmonary function in western red cedar workers related to duration of employment and dust exposure. Arch Environ Health 1986;41:179-83.

20. Baur X, Chen Z, Liebers V. Exposure-response relationships of occupational inhalative allergens. Clin Exp Allergy 1998;28:537-44.

21. Malo JL, Chan-Yeung M. Occupational asthma. J Allergy Clin Immunol 2001;108:317-28.

22. Gautrin D, Infante-Rivard C, Ghezzo H, Malo JL. Incidence and host determinants of probable occupational asthma in apprentices exposed to laboratory animals. Am J Respir Crit Care Med 2001;163:899-904.

23. Gautrin D, Ghezzo H, Infante-Rivard C, Malo JL. Host determinants for the development of allergy in apprentices exposed to laboratory animals. Eur Respir J 2002;19:96-103.

24. Caldeira RD, Bettiol H, Barbieri MA, Terra-Filho J, Garcia CA, Vianna EO. Prevalence and risk factors for work related asthma in young adults. Occup Environ Med 2006;63:694-9.

25. Poonai N, van Diepen S, Bharatha A, Manduch M, Deklaj T, Tarlo SM. Barriers to diagnosis of occupational asthma in Ontario. Can J Public Health 2005;96:230-3.

26. Pepys J, Hutchcroft BJ. Bronchial provocation tests in etiologic diagnosis and analysis of asthma. Am Rev Respir Dis 1975;112:829-59.

27. Perrin B, Cartier A, Ghezzo H, et al. Reassessment of the temporal patterns of bronchial obstruction after exposure to occupational sensitizing agents. J Allergy Clin Immunol 1991;87:630-9.

28. Malo JL, L'Archevêque J, Lummus Z, Bernstein D. Changes in specific $\operatorname{IgE}$ and $\operatorname{IgG}$ and monocyte chemoattractant protein-1 in workers with occupational asthma caused by diisocyanates and removed from exposure. J Allergy Clin Immunol 2006;118:530-3.

29. Tse KS, Chan H, Chan-Yeung M. Specific IgE antibodies in workers with occupational asthma due to western red cedar. Clin Allergy 1982;12:249-58.

30. Frew A, Chang JH, Chan $\mathrm{H}$, et al. T-lymphocyte responses to plicatic acid-human serum albumin conjugate in occupational asthma caused by western red cedar. J Allergy Clin Immunol $1998 ; 101: 841-7$. 
31. Lemière C, Malo JL, Boutet M. Reactive airways dysfunction syndrome due to chlorine: Sequential bronchial biopsies and functional assessment. Eur Respir J 1997;10:241-4.

32. Demnati R, Fraser R, Ghezzo H, Martin JG, Plaa G, Malo JL. Time-course of functional and pathological changes after a single high acute inhalation of chlorine in rats. Eur Respir J 1998;11:922-8.

33. Martin JG, Campbell HR, Iijima H, et al. Chlorine-induced injury to the airways in mice. Am J Respir Crit Care Med 2003; 168:568-74.

34. Gautrin D, Bernstein IL, Brooks SM. Reactive airways dysfunction syndrome or irritant-induced asthma. In: Bernstein IL, Chan-Yeung M, Malo JL, Bernstein DI, eds. Asthma in the Workplace, 3rd edn. New York: Taylor \& Francis, 2006:579-627.

35. Tarlo SM, Boulet LP, Cartier A, et al. Canadian Thoracic Society guidelines for occupational asthma. Can Respir J 1998;5:289-300.

36. Chan-Yeung M. Fate of occupational asthma. A follow-up study of patients with occupational asthma due to Western Red Cedar (Thuja plicata). Am Rev Respir Dis 1977;116:1023-9.

37. Le Moual N, Siroux V, Pin I, Kauffmann F, Kennedy SM. Asthma severity and exposure to occupational asthmogens. Am J Respir Crit Care Med 2005;172:440-5

38. Vandenplas O, Ghezzo H, Munoz X, et al. What are the questionnaire items most useful in identifying subjects with occupational asthma? Eur Respir J 2005;26:1056-63.

39. Kennedy SM, Le Moual N, Choudat D, Kauffmann F. Development of an asthma specific job exposure matrix and its application in the epidemiological study of genetics and environment in asthma (EGEA). Occup Environ Med 2000;57:635-41.

40. Cockcroft DW, Ruffin RE, Frith PA, et al. Determinants of allergen-induced asthma: Dose of allergen, circulating IgE antibody concentration, and bronchial responsiveness to inhaled histamine. Am Rev Respir Dis 1979;120:1053-8.

41. Pepys J. New tests to assess lung function. Inhalation challenge tests in asthma. N Engl J Med 1975;293:758-9.

42. Malo JL, Cartier A, Lemière $\mathrm{C}$, et al. Exaggerated bronchoconstriction due to inhalation challenges with occupational agents. Eur Respir J 2004;23:300-3.

43. Vandenplas $\mathrm{O}$, Malo JL. Inhalation challenges with agents causing occupational asthma. Eur Respir J 1997;10:2612-29.

44. Obata H, Dittrick M, Chan H, Chan-Yeung M. Sputum eosinophils and exhaled nitric oxide during late asthmatic reaction in patients with western red cedar asthma. Eur Respir J 1999;13:489-95.

45. Lemière $\mathrm{C}$, Pizzichini MM, Balkissoon R, et al. Diagnosing occupational asthma: Use of induced sputum. Eur Respir J 1999;13:482-8

46. Girard F, Chaboillez S, Cartier A, et al. An effective strategy for diagnosing occupational asthma. Use of induced sputum. Am J Respir Crit Care Med 2004;170:845-50.

47. Chan-Yeung M, Lam S, Koener S. Clinical features and natural history of occupational asthma due to western red cedar (Thuja plicata). Am J Med 1982;72:411-5.

48. Hudson P, Cartier A, Pineau L, et al. Follow-up of occupational asthma caused by crab and various agents. J Allergy Clin Immunol 1985;76:682-8.

49. Maghni K, Lemière C, Ghezzo H, Yuquan W, Malo JL. Airway inflammation after cessation of exposure to agents causing occupational asthma. Am J Respir Crit Care Med 2004;169:367-72.
50. Sumi Y, Foley S, Daigle S, et al. Structural changes and airway remodeling in occupational asthma at a mean interval of 14 years after cessation of exposure. Clin Exper Allergy. (In press)

51. Malo JL, Ghezzo H. Recovery of methacholine responsiveness after end of exposure in occupational asthma. Am J Respir Crit Care Med 2004;169:1304-7.

52. Malo JL, Cartier A, Boulet LP, et al. Bronchial hyperresponsiveness can improve while spirometry plateaus two to three years after repeated exposure to chlorine causing respiratory symptoms. Am J Respir Crit Care Med 1994;150:1142-5.

53. Côté J, Kennedy S, Chan-Yeung M. Outcome of patients with cedar asthma with continuous exposure. Am Rev Respir Dis 1990;141:373-6.

54. Malo JL, Cartier A, Côté J, et al. Influence of inhaled steroids on recovery from occupational asthma after cessation of exposure: An 18-month double-blind crossover study. Am J Respir Crit Care Med 1996;153:953-60.

55. Dewitte JD, Chan-Yeung M, Malo JL. Medicolegal and compensation aspects of occupational asthma. Eur Respir J 1994; 7:969-80

56. Malo JL. Compensation for occupational asthma in Quebec. Chest 1990;98:236S-9S.

57. American Thoracic Society. Medical Section of the American Lung Association. Guidelines for the evaluation of impairment/disability in patients with asthma. Am Rev Respir Dis 1993;147:1056-61.

58. Cocchiarella L, Andersson GBJ, eds. Guides to the Evaluation of Permanent Impairment, 5th edn. Chicago: American Medical Association, 2001.

59. Chan-Yeung M, Obata H, Dittrick M, Chan H, Abboud R. Airway inflammation, exhaled nitric oxide, and severity of asthma in patients with western red cedar asthma. Am J Respir Crit Care Med 1999;159:1434-8.

60. Malo JL, Boulet LP, Dewitte JD, et al. Quality of life of subjects with occupational asthma. J Allergy Clin Immunol 1993;91:1121-7.

61. Al-Otaibi S, Tarlo SM, House R. Quality of life in patients with latex allergy. Occup Med (Lond) 2005;55:88-92.

62. Tarlo SM, Liss GM. Prevention of occupational asthma - practical implications for occupational physicians. Occup Med (Lond) 2005;55:588-94.

63. Nicholson PJ, Cullinan P, Taylor AJ, Burge PS, Boyle C. Evidence based guidelines for the prevention, identification, and management of occupational asthma. Occup Environ Med 2005;62:290-9

64. Tarlo SM, Liss GM. Diisocyanate-induced asthma: Diagnosis, prognosis, and effects of medical surveillance measures. Appl Occup Environ Hyg 2002;17:902-8.

65. Bersntein Il, Keskinen H, Blanc PD, Chan-Yeung M, Malo JL. Medicolegal aspects, compensation aspects, and evaluation of impairment/disability. In: Bernstein IL, Chan-Yeung M, Malo JL, Bernstein DI, eds. Asthma in the Workplace, 3rd edn. New York: Francis \& Taylor, 2006:319-51.

66. Gautrin D, Ghezzo H, Infante-Rivard C, Malo JL. Natural history of sensitization, symptoms and occupational diseases in apprentices exposed to laboratory animals. Eur Respir J 2001;17:904-8.

67. Tarlo SM, Malo JL. An ATS/ERS report: 100 key questions and needs in occupational asthma. Eur Respir J 2006;27:607-14.

68. Chan-Yeung M, Malo JL. Occupational asthma. N Engl J Med 1995;333:107-12. 


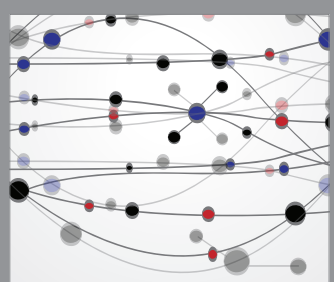

The Scientific World Journal
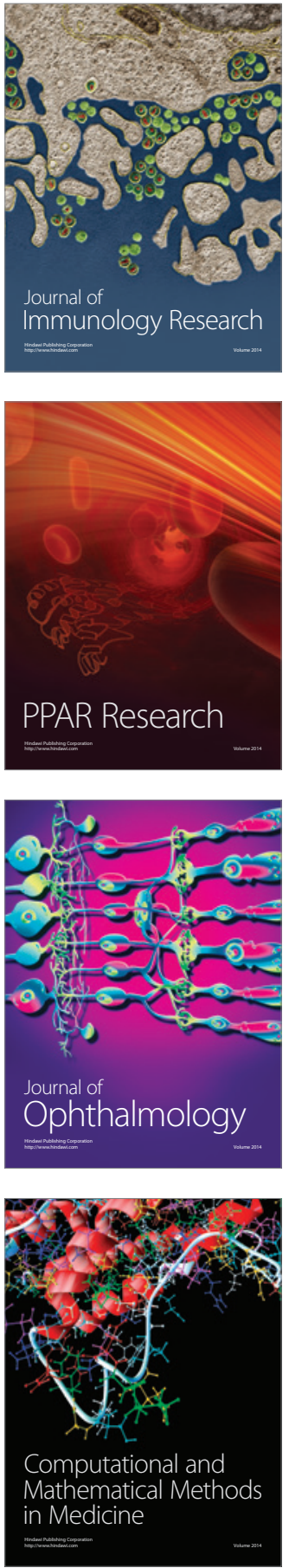

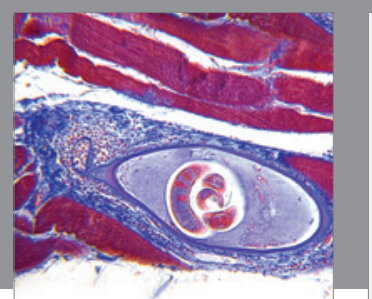

Gastroenterology Research and Practice

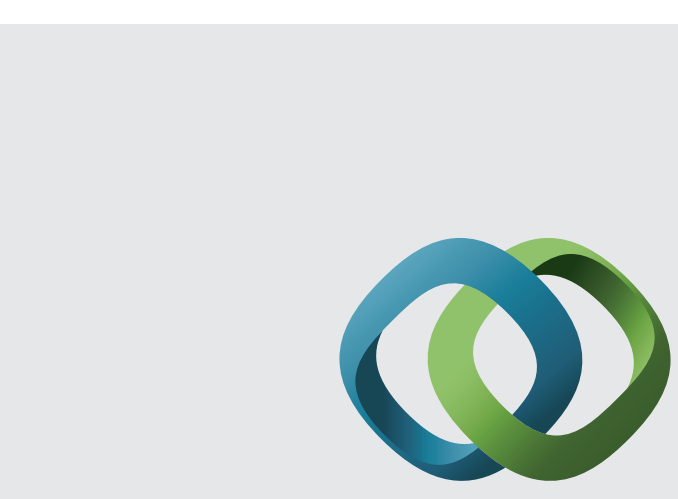

\section{Hindawi}

Submit your manuscripts at

http://www.hindawi.com
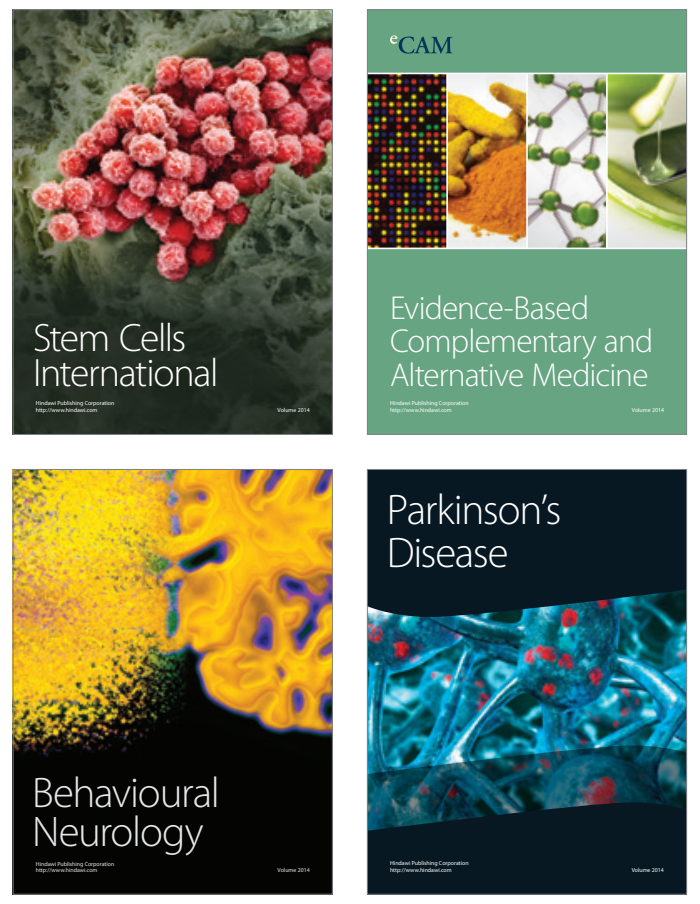
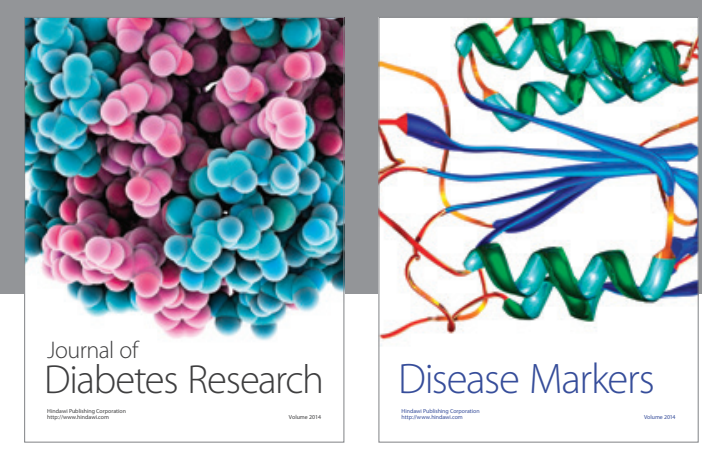

Disease Markers
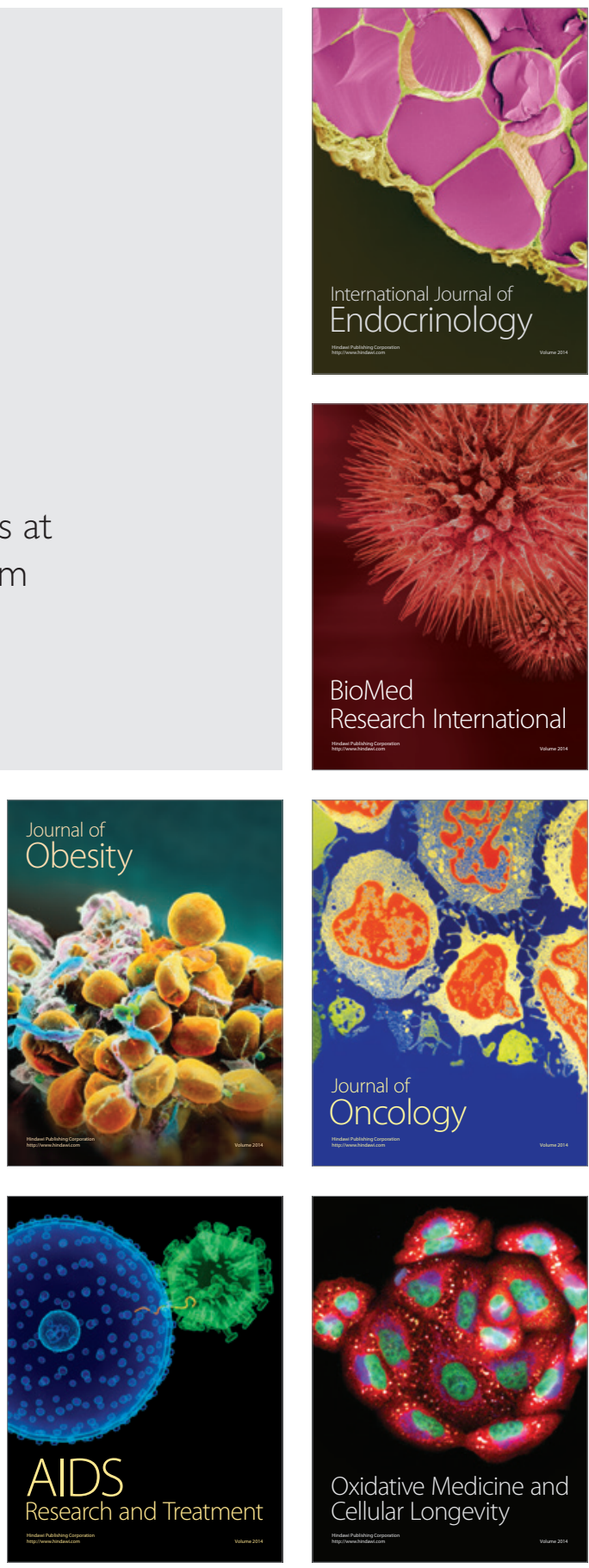